\title{
The Effect of Financial and Non-Financial Compensation on Employee Performance Kentucky Fried Chicken (KFC) Pettarani Makassar
}

\author{
Muhtazib $^{1}$, Andi Niartiningsih ${ }^{2}$ \\ Corresponding Email: muhtasibibha@gmail.com \\ ${ }^{1}$ Management Study Program, Faculty of Social Sciences, Economics and Humanities, \\ Cokroaminoto University Makassar, Indonesia \\ ${ }^{2}$ Hospital Administration Study Program, Faculty of Health Sciences, Cokroaminoto \\ University Makassar, Indonesia
}

Received: January 3, 2021

Revised: February 1, 2022

Accepted: February 7, 2022

\begin{abstract}
The purpose of this study is to determine the effect of financial compensation on the performance of KFC Pettarani Makassar employees, the effect of non-financial compensation on the performance of KFC Pettarani Makassar employees, and the effect of financial and nonfinancial compensation on the performance of KFC Pettarani Makassar employees concurrently. The sample for this research consisted of 42 respondents who were randomly assigned to work at KFC Pettarani Makassar. The classical assumption test, multiple linear regression analysis, $\mathrm{T}$ test, correlation analysis, and determination are all employed in this work. The results indicate that the hypothesis of financial compensation having an effect on employee performance is accepted based on the calculated $\mathrm{T}$ value of 3.357 , which is greater than the T table value of 1.68488; the hypothesis of non-financial compensation having an effect on employee performance is accepted based on the calculated T value of 2.619, which is greater than the $\mathrm{T}$ table value of 1.68488; and financial compensation and non-financial compensation both have an effect on employee performance based on the calculated $\mathrm{T}$ values of The correlation coefficient test indicates that financial compensation and non-financial compensation have a strong relationship with employee performance, and the determination test indicates that financial compensation and non-financial compensation account for 51.1 percent of employee performance. It is advised that more attention be paid to the supply of incentive pay, so that by providing such compensation, the organization may increase its workers' performance; also, it is determined if the distribution is regular and the quantity offered is appropriate.
\end{abstract}

Keywords: Financial Compensation, Non-Financial Compensation, Employee Performance

Introduction

In a period of global competitiveness, the availability of dependable human resources is more important than the availability of other resources in terms of strategic importance. While human resources are the most valuable assets that an organization has, successful organization management is the most significant factor in the achievement of organizational goals (Berson \& Avolio, 2004).

Aware of the critical role that human resources play in the survival and growth of a business (Solomon et al., 2013), a company must devote special attention to this factor of production (Guerci \& Carollo, 2016; Vuontisjärvi, 2006; Becker \& Gerhart, 1996), and it is only natural that company owners view human resources as more than just company assets and consider them to be partners in the business. The company must be able to be fair for what has been 
provided by human resources to the company, because every employee has the right to receive appreciation and fair treatment from his or her leadership in exchange for the services that they provide, and this will encourage employees to be more motivated in carrying out their responsibilities as employees in the long run. worker. In order to boost employee morale, a mutually beneficial working relationship between the organization and its workers is required. Employees contribute to the success of the business by providing excellent job performance, and the firm responds by providing suitable remuneration in exchange for the excellent work performance that employees have provided to the organization (Markos \& Sridevi, 2010; Hameed et al., 2014).

There have been ups and downs in the performance of the KFC Pettarani Makassar personnel throughout the year 2019 to 2021, which may be attributed to a number of different variables. In 2019, exceptional results were achieved in the employee performance process, which coincided with increasing sales and transactions. This also increases the company's interest in monitoring the performance of its personnel as a result of this. There are two variables that influence the performance spirit of KFC Pettarani Makassar employees: the pay offered by the firm, both financial and non-financial, and the environment in which they work. It is initially considered from a financial standpoint, which includes salary and bonuses, as well as allowances and incentives. KFC Pettarani Makassar provides equal opportunities to all of its employees, both financially and non-financially, including opportunities for advancement and submission of permanent employees, social security, vacation (outing), health coverage and insurance, as well as a pleasant working environment.

Although the COVID 19 pandemic or the corona virus has exerted significant pressure on the Indonesian economy since the beginning of 2020, specifically in March, the license holder for KFC fast food restaurant outlets, PT Fast Food Indonesia Tbk. (FAST), has acknowledged a decline in sales value and the number of transactions as a result. As a result, the corporation decides to adopt strategic initiatives in order to concentrate on operational activity.

A drop in sales and transactions was also seen by other businesses, like KFC Pettarani Makassar. During a pandemic, when the number of COVID 19 or corona virus transmissions grows, activities outside the house are restricted, resulting in a reduction in the number of consumers who go shopping. As a result, he has also become the owner of PT. Fast Food Indonesia since that time. TBK. opted to adhere to health norms or government rules, which included operating hours limits. Previously, KFC Pettarani was open 24 hours a day, seven days a week, closing at 10 p.m. and only accepting take-out orders through take-out SMS. Seeing that sales and transactions are declining on a daily basis as a result of the COVID-19 epidemic, the firm does not keep mute, and as a result, the company releases several promotions in order to lure consumers to shop.

In addition, the management of KFC Pettarani indicated that the number of workers from early March 2019 to early March 2020 was around 50, which included both permanent and contract staff, according to the company. However, once the COVID-19 pandemic started, which was exactly in March 2020, the number of workers at KFC Pettarani Makassar has begun to decline gradually and steadily. There have been no layoffs, but there are a significant number of workers whose contracts have not been renewed, as well as a significant number of people who have been laid off. Until now, the remaining 36 staff have been able to do their duties. In addition, all KFC workers in Indonesia, including those at KFC Pettarani Makassar, would see a 30 percent pay drop.

As a result, employee performance has been negatively impacted both prior to the COVID-19 pandemic and as the pandemic has progressed until now, as a result of a variety of factors, 
including, as previously mentioned, the number of employees laid off and the salaries/wages of employees being reduced.

A study with the title "The Effect of Financial and Non-Financial Compensation on Employee Performance of KFC Pettarani Makassar" is being considered by the writers based on the information provided above.

\section{Methods}

This study is situated in KFC Pettarani Makassar Jln. AP. Pettarani Makassar in Makassar, Indonesia. The sort of research employed in this study is quantitative research using a descriptive technique, which is the most common. The participants in this research were all workers of KFC Pettarani Makassar, with a total population of 42 participants in this study. The sample for this research will be drawn from all of the workers of KFC Pettarani Makassar, a total of 42 persons who will be made up of many employees who will hold diverse jobs. Interviews, observation, and documentation were used to gather information for this research.

In order to have a better understanding of the research topic, univariate analysis was carried out by explaining each variable that was employed in the study, as well as the characteristics of the respondents. Descriptive analyses of respondents' characteristics were carried out, as well as descriptive analyses of research factors, and crosstabulation analyses were carried out between respondents' characteristics and research variables in the univariate analysis. It was necessary to do a bivariate analysis in order to determine the influence of two variables, namely, the relationship between the independent and dependent variables. It was decided to apply the chi-square test for the statistical analysis, and logistic regression analysis was employed for the multivariate analysis

\section{Results and Discussion}

\section{Descriptive Statistics}

Table 1. Hypothesis Test Results

\begin{tabular}{|c|c|c|c|c|}
\hline Code & Relationship Between Variables & Coefficient & P Values & Description \\
\hline H1 & $\begin{array}{c}\text { Financial compensation - > employee } \\
\text { performance }\end{array}$ & 3.357 & 0.023 & Accepted \\
\hline H2 & $\begin{array}{c}\text { Non-Financial Compensation - > } \\
\text { Employee Performance }\end{array}$ & 2.619 & 0.019 & Accepted \\
\hline H3 & $\begin{array}{c}\text { Financial and Non-Financial } \\
\text { Compensation - > Employee Performance }\end{array}$ & 4.213 & 3.24 & Accepted \\
\hline
\end{tabular}

According to the information in the table above, hypothesis testing may be characterized as follows. The first hypothesis is accepted because financial remuneration has a positive influence on employee performance with a 3.357 coefficient and is statistically significant with a $\mathrm{P}$ value of 0.023 that is not more than 0.05 . Non-financial compensation has a positive impact on employee performance of 2,619 and is statistically significant with a $\mathrm{P}$ value of 0.019 that is not more than 0.05 , indicating that the second hypothesis is accepted. The combined impact of financial and non-financial compensation is 4.213 , which is more than 3.24 , and hence the third hypothesis is supported.

Following the results of data analysis, it is expected that employees will be able to carry out their duties and perform well at their jobs after making observations using a questionnaire as a data collection medium, which is then analyzed using multiple regression tests using the SPSS 24 software program, which is used to analyze the results of the data analysis. The fact that Tcount is bigger than Ttable $(3,357>1,68488)$ demonstrates that financial remuneration has

Copyright (C) 2022, Journal of Asian Multicultural Research for Economy and Management Study, Under the license CC BY-SA 4.0 
an impact on employee performance, and so the premise that financial compensation has an impact on employee performance is demonstrated to be correct. According to Dito (2010), who performed a study titled "The Effect of Compensation on Employee Performance at PT. Slamet Langgeng Purbalingga with Motivation as an Intervening Variable," these findings are validated by research. The following are the findings of the researcher: Employee performance is significantly influenced by their compensation in a favorable and substantial way. Employee performance is influenced by remuneration in an indirect manner via performance motivation; hence, it can be inferred that motivation is a variable that mediates the relationship between compensation and employee performance. Azmi (2009), Yulianti (2002), Masrur \& Färber (2006), and Chanifah (2007) conducted more study to determine if financial pay has a substantial impact on employee performance.

The researchers may thus infer that financial remuneration has a positive impact on improving employee performance, as indicated by the findings of a study performed by researchers on workers of Kentucky Fried Chicken (KFC) Pettarani Makassar in Indonesia.

Using non-financial compensation data analysis, it is anticipated that employees will be able to carry out their responsibilities and work effectively. After collecting data through a questionnaire and analyzing the results using the SPSS 24 program, it is predicted that employees will be able to carry out their responsibilities and work effectively. The results of Tcount greater than Ttable $(2.619>1.68488)$ demonstrate that financial compensation has an impact on employee performance, and thus the hypothesis stating that financial compensation has an impact on employee performance is proven to be correct.

According to study data collected by academics, non-financial remuneration is a variable that serves as a standard for improving employee performance. These findings are corroborated by research conducted by Yulianti (2002), who was involved in a study titled "The Influence of Compensation on the Performance of Employees Researchers conducted a study on the employees of the company Achmad Kunci Kediri's production division "explains that there is a very close relationship between compensation and performance, and that both direct and indirect compensation have a significant impact on the performance of its employees. 88.3 percent of those who participated in this survey felt that they were in a close relationship.

This is supported by research from Yulianti (2002), Azmi (2004), Masrur \& Färber (2006) (2006), Chalifah (2007), who conducted a study entitled The Effect of Compensation on Employee Performance based on the results of simultaneous data analysis through financial compensation and non-financial compensation. It has been discovered via employee research that there is a very strong link between remuneration and employee performance, with both direct and indirect compensation having a major impact on employee performance.

\section{Conclusion}

The findings revealed that financial compensation and non-financial compensation had a significant impact on employee performance, and the results of the determination test revealed that the combined contribution of financial compensation and non-financial compensation accounted for 51.1 percent of total performance. We urge that the supply of incentive compensation get greater attention in order to increase the performance of its workers. In addition, it should be examined if the distribution is regular or not, as well as whether the amount awarded is appropriate or not.

\section{References}

Azmi, I. A. G. (2009). Human capital development and organizational performance: a focus on Islamic perspective. Jurnal Syariah, 17(2), 353-372. 
Becker, B., \& Gerhart, B. (1996). The impact of human resource management on organizational performance: Progress and prospects. Academy of management journal, 39(4), 779-801.

Berson, Y., \& Avolio, B. J. (2004). Transformational leadership and the dissemination of organizational goals: A case study of a telecommunication firm. The leadership quarterly, 15(5), 625-646.

Chanifah, U. (2021). Analisis Pengelolaan Persediaan Barang Dagang Dengan Metode Economic Order Quantity (EOQ) Pada Toko Dhyfaka Collection(Doctoral dissertation, Politeknik Harapan Bersama Tegal).

Dito, A. H., \& Lataruva, E. (2010). Pengaruh kompensasi Terhadap kinerja karyawan PT. Slamet langgeng purbalingga Dengan motivasi kerja Sebagai variabel intervening (Doctoral dissertation, UNIVERSITAS DIPONEGORO).

Guerci, M., \& Carollo, L. (2016). A paradox view on green human resource management: Insights from the Italian context. The International Journal of Human Resource Management, 27(2), 212-238.

Hameed, A., Ramzan, M., \& Zubair, H. M. K. (2014). Impact of compensation on employee performance (empirical evidence from banking sector of Pakistan). International journal of business and social science, 5(2).

Markos, S., \& Sridevi, M. S. (2010). Employee engagement: The key to improving performance. International journal of business and management, 5(12), 89.

Masrur, A., \& Färber, G. (2006). Ideas to improve the performance in feasibility testing for edf. In Proceedings of the 18th Euromicro Conference on Real-Time Systems (ECRTS)(Work in Progress Session).

Solomon, G. T., Bryant, A., May, K., \& Perry, V. (2013). Survival of the fittest: Technical assistance, survival and growth of small businesses and implications for public policy. Technovation, 33(8-9), 292-301.

Vuontisjärvi, T. (2006). Corporate social reporting in the European context and human resource disclosures: An analysis of Finnish companies. Journal of business ethics, 69(4), 331354.

Yulianti, K. S. (2006). Analisis Faktor-Faktor Yang Mempengaruhi Rasa Percaya Outlet Pada Perusahaan Untuk Meningkatkan Loyalitas (Studi Kasus Pada Outlet Jamu Ny. Meneer di Semarang) (Doctoral dissertation, Program Pascasarjana Universitas Diponegoro). 